\title{
TRANSFORMATIONS IN THE OWNERSHIP OF THE SZCZECIN AND ŚWINOUJŚCIE SEAPORTS AUTHORITY BETWEEN 1991 AND 2000
}

\author{
by Małgorzata Kamola-Cieślik
}

Transformations in the ownership of state owned companies in Poland after 1989 played a pivotal role in the general political transformation which took place in Poland at that time. Those ownership changes were an essential element of the political transformation of Poland. The process of transforming the country's economy from central economic planning to free market economy was started by Tadeusz Mazowiecki's government. ${ }^{1}$ On October 9, 1989, the Council of Ministers accepted a document Guidelines and Directions of Poland's Economic Policy ${ }^{2}$ which aimed at stabilizing the country's economy and at transforming its economic system. The stabilization programme was supposed to be implemented by January, 1990. ${ }^{3}$ The second stage of the governmental plan was planned for the

1 W. Wilczyński, Polski przełom ustrojowy 1989-2005. Ekonomika epoki transformacji, Poznań 2005, p. 92.

2 Polityka gospodarcza w programach rządów polskich z lat 1989-1997. Wybór źródeł, Compiled by M. Kamola-Cieślik, Toruń 2009, pp. 43-50.

3 The economic stabilization programme was supposed to prevent monopolistic policies, foster active policy towards creating commodity reserves in order to intervene in the market, stop production in companies with high consumption of raw materials and energy for a production unit, introduce methods of long-term saving, cutting the 
years 1990-1991 and one of its main tenets was a transformation of ownership rights. Krzysztof Lis, ${ }^{4}$ the government's plenipotentiary for ownership transformation, was responsible for the organization and legislation of the process of privatizing Polish economy. T. Mazowiecki's cabinet prepared both a draft for the new amendment of the legal act concerning state owned companies and a draft of a new act about privatizing state owned companies.

On December 28, 1989, the Sejm (the lower house of the Polish People's Republic) adopted a set of guidelines of the economic stabilization programme (i.e. the so-called the Balcerowicz Plan) which consisted of 10 acts of law. ${ }^{5}$ The implementation of the Balcerowicz Plan on January 1st, 1990, meant that the rules and mechanisms of the free market economy were going to be implemented, which in turn started the process of ownership transformation. The privatization process also included sea companies such as The Szczecin and Świnoujście Seaports Authority (ZPS-Ś).

The aim of this paper is to present the stages of ownership transformation of The Szczecin and Świnoujście Seaport Authority between 1989 and 2000. Activities of the government, the company's board and the trade union during that time are presented in the paper. An analysis of the available documents attempts to discuss problems which arose during the transformation period.

The reference materials of the subject in question are the basis of this present paper. Poland's nationwide and local press was a contribution to the source materials. The study mainly used the method of institutionallegal and comparative analyses, which demonstrated the course of The Szczecin and Świnoujście Seaports Authority's privatization.

national defense budget. M. Bałtowski. M. Miszewski, Transformacja gospodarcza w Polsce, Warszawa 2006, pp. 188-189.

4 Polityka gospodarcza $w$ programach rządów polskich..., op.cit., p. 95.

5 M. Kamola-Cieślik, Kierunki prywatyzacji polskiej gospodarki w latach 1990-1991, „Przegląd Politologiczny” 2006, no. 4, p. 136. 
On July 13, 1990, the Sejm adopted a resolution about privatization of state-owned companies, ${ }^{6}$ which tried to make it possible to implement the process of ownership transformation. On the one hand, the regulations of this act were supposed to lead to restructuring and privatization of the already existing firms. However, on the other hand, they were meant to increase the number of small and medium-sized companies. At the same time, provisions were made to take advantage of foreign investment capital together with transfer of modern technologies and efficient methods of management. The adopted document suggested two methods of privatizing the state owned sector, i.e. transforming state owned firms into joint-stock companies as well as privatization of state owned firms through liquidation. $^{7}$

The Szczecin and Świnoujście Seaports Authority as the first state owned company in West Pomerania began the process of transforming the structure of ownership. An application was written to the Ministry of Transport and Marine Economy as well as to the Antimonopoly Office to transform the firm into a commercial company.

On May 10, 1991, according to the act on privatizing state owned firms, the company was transformed into a joint-stock company wholly owned by the State Treasury. ${ }^{8}$

The activity of the company focused on administrating, running and using its port facilities, providing harbor piloting and towing services as well as providing service and maintenance of sea vessels. ${ }^{9}$

The power in the company was wielded by the board, the supervisory board and the general meeting. The board was supposed to manage ad

6 Ustawa z dnia 13 lipca, 1990, o prywatyzacji przedsiębiorstw państwowych. Dz.U. 1990 Nr 51, poz. 298 [the Privatization of State-Owned Enterprises Act of July 13, 1990; Journal of Laws of the Republic of Poland No. 51 of 1990, item 298].

7 Ibidem.

8 The creation, organization and functioning of joint - stock companies are regulated by The Commercial Companies Code. J. Engelhardt, Typologia przedsiębiorstw, Warszawa 2009, p. 37; Leksykon prywatyzacji, Warszawa 1998, p.193.

9 Archiwum Państwowe w Szczecinie (APS) [The State Archive in Szczecin], Zarząd Portu Szczecin-Świnoujście (ZPS-Ś), catalogue number (cat. no.) 1489, card (c.) 1-2, Wniosek o wpis do rejestru handlowego Spółki Akcyjnej o nazwie "Zarząd Portu Szczecin-Świnoujście”, Szczecin, May 15, 1991. 
represent the company. It consisted of five people and it was presided over by a chairman. From May, 1991 to June, 1998, Dionizy Michał Popik was the company's chairman to be replaced in July with Andrzej Montwiłł. ${ }^{10}$ The supervisory board appointed and dismissed representatives of the company's board. It was a supervisory body responsible for controlling the company's operations, its balance, its profit and loss account and its annual report. It consisted of 9 persons, six of whom were appointed by the General Meeting and the remaining three were appointed by the company's employees. Jarosław Wdziękoński was the Chairman of the company's Supervisory Board at that time.

The newly created joint-stock company-The Szczecin and Świnoujście Seaports Authority-took over all the assets and property of the former firm, which included real estate, plots of land in the ports of Szczecin and Swinoujście together with its facilities. The share capital of the company amounted to 100 bln PLN.

Commercialization was the first stage of the process of changing the ownership structure of the company. In July, 1991, the board of The Szczecin and Świnoujście Seaports Authority joint-stock company decided to set up commercial companies together with its employees on the basis of the already existing organizational units of the company.11 Due to a lack of legal regulations in the matter of land ownership, this was the only possible form of ownership transformation to be conducted in the company. The idea of forming commercial companies was accepted by the Supervisory Board of the company ${ }^{12}$ and by the Ministry of Ownership Transformation. The plans of changing the ownership and structure of the company also gained the acceptance of its employees. In order to prepare the company for the process of changing its ownership structure the company's board appointed Ryszard Dzikowski as the company's plenipotentiary for ownership transformation. During the sessions of the

\footnotetext{
10 Ibidem, cat. no. 1767, c. 124, Protokół z posiedzenia Rady Przedsiębiorstw Portowych w dniu 9 lipca $1998 \mathrm{r}$.

11 Ibidem, cat. no. 1680, c. 22, Protokół Nr 2 z posiedzenia Rady Nadzorczej Spółki Akcyjnej Zarząd Portu Szczecin-Świnoujście w dniu 17 lipca $1991 \mathrm{r}$.

12 Ibidem, c. 30, Uchwała Nr 7 Rady Nadzorczej Spółki Akcyjnej Zarząd Portu Szczecin-Świnoujście podjęta 17 lipca $1991 \mathrm{r}$.
} 
company's board the plenipotentiary presented privatization plans, methods of implementing ownership changes and the positions of port companies and trade unions involved in the process.

Between August and September 1991, on the basis of internal organizational units (departments) of the company, seventeen limited liability companies (Table 1) with a holding-like structure were created. The creation of port companies started the process of separating the operational-commercial sphere from the management of the port's area and infrastructure. At the same time a more effective structure of the port was created. Between The Szczecin and Świnoujście Seaports Authority and the respective companies contracts were signed regulating their mutual cooperation. ${ }^{13}$ The main idea of creating a new company was to employ all the workers which up till then worked for that particular organizational unit of the original company. All the members of the company's governing bodies (including the employees and people who were not employed in the company) had to be the company's capital shareholders (a minimum of $500,000.00$ PLN).${ }^{14}$ All the shares amounted to $55 \%$ of the initial capital and the rest belonged to The Szczecin and Świnoujście Seaports Authority S.A. (SSSSA). The subsidiary companies conducted trans-shipment and warehouse business, according to contracts made by the SSSA taking advantage of the facilities owned by the State Treasury (and represented by the company) on the basis of lease contracts. The port company had control over the assets and wealth of the leased companies.

On 24 October, 1991, SŚSA together with seventeen port companies created The Council of Port Companies. ${ }^{15}$ The Chairman of the Port Authorities became its President. The Council while being an advisory and consultative body became a forum of exchanging ideas and experiences on operational and commercial activities, directions of developing port facilities, rules of cooperating between respective companies. ${ }^{16}$

13 Ibidem, cat. no. 1489, c. 36, Umowa ogólna o zasadach wzajemnej współpracy, Szczecin, 19 września $1991 \mathrm{r}$.

14 Ibidem, cat. no. 1680, c. 49-51, Przekształcenia własnościowe ZPS-Ś SA z udziałem spółek pracowniczych, Szczecin, 4 lipca1991 r.

15 Ibidem, cat. no. 1763, c. 2-6, Regulamin Rady...

16 Ibidem, c. 4-5. 
Table 1: A list of limited liability companies created on the basis of internal organizational units

\begin{tabular}{|c|c|c|c|}
\hline $\begin{array}{c}\text { Organizational } \\
\text { unit of SŚSA }\end{array}$ & $\begin{array}{l}\text { Newly } \\
\text { created company }\end{array}$ & $\begin{array}{c}\text { Start } \\
\text { of activity }\end{array}$ & Chairman \\
\hline Repair Department I & Port Crane Service & 10.09 .1991 & Wacław Iwanowski \\
\hline Repair Department II & Port-Rem & 16.09.1991 & Zbigniew Gazdowski \\
\hline Repair Department III & $\begin{array}{l}\text { Potowy Zakład Remon- } \\
\text { towy }\end{array}$ & 14.09 .1991 & Stanisław Pyź \\
\hline Repair Department IV & $\begin{array}{l}\text { Zakład Napraw Taboru } \\
\text { Pływającego Navirem }\end{array}$ & 19.09.1991 & $\begin{array}{l}\text { Andrzej Andrzejew- } \\
\text { ski }\end{array}$ \\
\hline $\begin{array}{l}\text { Engineering - Building } \\
\text { Departament }\end{array}$ & Bud-Port & 1.10 .1991 & Stanisław Żytkowski \\
\hline $\begin{array}{l}\text { Electronics and Commu- } \\
\text { nication Department }\end{array}$ & Tel-Port & 14.09.1991 & Roman Zaworski \\
\hline $\begin{array}{l}\text { Motor Transport Depart- } \\
\text { ment }\end{array}$ & Trans-Port Service & 25.09.1991 & $\begin{array}{l}\text { Mirosław Kachno- } \\
\text { wicz }\end{array}$ \\
\hline $\begin{array}{l}\text { Shipping and Warehouse } \\
\text { Department I DP-I }\end{array}$ & $\begin{array}{l}\text { Przedsiębiorstwo Usług } \\
\text { Portowych Ewa-Stevedo- } \\
\text { ring }\end{array}$ & 11.09.1991 & Tadeusz Zdanowicz \\
\hline $\begin{array}{l}\text { Shipping and Warehouse } \\
\text { Department II DP-II }\end{array}$ & $\begin{array}{l}\text { Przedsiębiorstwo Usług } \\
\text { Portowych Elewator-Ewa }\end{array}$ & 11.09.1991 & $\begin{array}{l}\text { Wojciech Kaźmier- } \\
\text { czak }\end{array}$ \\
\hline $\begin{array}{l}\text { Shipping and Warehouse } \\
\text { Department IIi DP-IIi }\end{array}$ & $\begin{array}{l}\text { Przedsiębiorstwo Usług } \\
\text { Portowych Łasztownia }\end{array}$ & 25.09 .1991 & Ryszard Chojnowski \\
\hline $\begin{array}{l}\text { Shipping and Warehouse } \\
\text { Department IV DP-IV }\end{array}$ & $\begin{array}{l}\text { Przedsiębiorstwo Usług } \\
\text { Portowych Starówka }\end{array}$ & 6.09 .1991 & Mirosław Bogucki \\
\hline $\begin{array}{l}\text { Shipping and Warehouse } \\
\text { Department V DP-V }\end{array}$ & $\begin{array}{l}\text { Przedsiębiorstwo Usług } \\
\text { Portowych Cargo-Port }\end{array}$ & 5.09 .1991 & Bogusław Trzciński \\
\hline $\begin{array}{l}\text { Shipping and Warehouse } \\
\text { Department VI DP-VI }\end{array}$ & $\begin{array}{l}\text { Przedsiębiorstwo Usług } \\
\text { Portowych Coal-Port }\end{array}$ & 16.09.1991 & Jerzy Jezierski \\
\hline $\begin{array}{l}\text { Shipping and Warehouse } \\
\text { Department VII DP-VII }\end{array}$ & $\begin{array}{l}\text { Przedsiębiorstwo Usług } \\
\text { Portowych Mas-Port }\end{array}$ & 14.09.1991 & Roman Stecyk \\
\hline $\begin{array}{l}\text { Shipping Unit in Świno- } \\
\text { ujście }\end{array}$ & $\begin{array}{l}\text { Port Handlowy Świnouj- } \\
\text { ście }\end{array}$ & 16.09 .1991 & Piotr Krygiel \\
\hline Navigation Services & $\begin{array}{l}\text { Zakład Usług Żeglugo- } \\
\text { wych }\end{array}$ & 1.10 .1991 & Ryszard Gulbinowicz \\
\hline Central Port Company & $\begin{array}{l}\text { Portowe Centralne } \\
\text { Warsztaty Mechaniczne }\end{array}$ & 26.09.1991 & Tadeusz Szulc \\
\hline
\end{tabular}

The author's own material on the basis of: APS, ZPS-S, cat. no. 1759, c. 126-127, Wykaz spółek z ograniczoną odpowiedzialnością, Szczecin, 25 września1991 r.; Ibidem, cat. no. 1763, c. 2-3, Regulamin Rady Przedsiębiorstw Państwowych, Szczecin, wrzesień $1991 \mathrm{r}$. 
The creation of port companies on the basis of the organizational units of SŚSA triggered the mechanism of effective managing the port. Within the first years of their activity the port companies generated profits. Their total gross profit in 1992 was 131,039 mln PLN and in 1993-246,668 mln PLN. ${ }^{17}$ At the same time the port recorded an increase in the trans-shipment. 12,300,000 tons were handled in the port in 1992 and 14,400,000 tons in $1993 .{ }^{18}$

On October 11, 1993, the company's board while continuing to implement the process of transforming the ownership structure adopted a plan; Proposals of Privatization Methods of SSSSA. ${ }^{19}$ A month later the document was given a positive opinion by the company's supervisory board, which at the same time obliged the government to implement it. On November 22,1993 , the government drew up A schedule of preparations necessary to implement privatization plan for SŚSA SA. ${ }^{20}$ The program and schedule of privatization had been accepted by trade unions and The Council of Port Companies and sent to the Ministry of Ownership Transformation.

The privatization of SSSSA was an attempt to strengthen the position of the company functioning as one organism on the market of port services. The activities were supposed to include: a fusion of the already existing port companies into larger structures, transformation of port limited liability companies into joint-stock companies, sale of the companies' shares to their employees. ${ }^{21}$

The principles of the privatization plan had to be approved by the Ministry of Ownership Transformation and in particular the evaluation

\footnotetext{
17 Ibidem, cat. no. 1689, c. 144, Podstawowe wielkości ekonomiczne i wskaźniki oceny wyników finansowych w spółkach z o.o. za 1992/1993 rok.

18 Ibidem, cat. no. 1336, c. 4, „Zarząd Portu Szczecin-Świnoujście” Spółka Akcyjna - historia, plany i szanse rozwoju.

19 Ibidem, cat. no. 1490, c. 76-93, Informator o przekształceniach strukturalno-własnościowych ZPS-Ś SA.

20 Ibidem, c. 37-39, Harmonogram działań przygotowawczych do wdrożenia programu prywatyzacji ZPS-Ś SA.

21 Ibidem, c. 78, Informator o przekształceniach...
} 
procedures of different elements of the suprastructure and how shares of the respective companies can be made available. ${ }^{22}$

Between April and May 1994 the general meeting of the port companies adopted a resolution calling for a fusion of these companies. The newly created companies had different names, different business objectives and their company capital has been increased. As a result of the process the following cargo handling companies were created: Drobnica-Port Szczecin Sp. z o.o. ${ }^{23}$ (limited liability company) and Bulk Cargo-Port Szczecin Sp. z o.o. ${ }^{24}$. The newly created repair companies included: Port Crane Service Sp. z o.o. (limited liability company) and PCWM-Navirem Sp. z o. o. (limited liability company). Infra-Port Sp. z o.o. ${ }^{25}$ became the newly founded port infrastructure company. The fusion process did not include two cargo - handling companies: Elewator-Ewa ${ }^{26}$ and Port Handlowy Świnoujście ${ }^{27}$ and one navigational company-Zakład Usług Żeglugowych. ${ }^{28}$ Those were limited liability companies.

On August 8, 1994, the Ministry of Ownership Transformation confirmed the legitimacy of the fusion process of port companies as the implementation of one principle of the privatization plan for SŚSA SA. ${ }^{29}$ However, the minister did not make a statement about the sale of the suprastructure elements or the sale of the port companies' shares. ${ }^{30}$

${ }^{22}$ Issues concerning the fusion of limited liability companies and their transformation into joint-stock companies are regulated by the Commercial Code Act 283-289. Rozporządzenie Prezydenta Rzeczypospolitej z dnia 27 czerwca 1934 r. Kodeks handlowy. DzU 1934, nr 57, poz. 937 [By virtue of the President's ordinance of June 27, 1934. Commercial Code. Journal of Laws of the Republic of Poland No. 57 of 1937, item 937].

23 http://www.port.szczecin.pl/index.php?option=com_content\&task=view\& id=336\&Ite..., 6.04.2010.

$24 \mathrm{http}: / /$ www.bukcargo.com.pl/index2.php?=pl\&mod=firma\&cid=4, 6.04.2010.

$25 \mathrm{http}: / /$ wwwinfraport.pl/?o-firmie, 6.04.2010.

$26 \mathrm{http} / / /$ www.elewator-ewa.szczecin.pl/historia.html, 6.04.2010.

27 http://www.phs.com.pl/index.php?page=o-firie, 6.04.2010.

28 http://www.zuz.pl/vphp/onas.htm, 6.04.2010.

29 APS, ZPS-Ś, cat. no. 1724, c. 43, Informacja o realizacji programu prywatyzacji Zarządu Portu Szczecin-Świnoujście.

30 Ibidem, cat. no. 1490, c. 95, Opinia prawna w sprawie dopuszczalności oraz zakresu realizacji programu prywatyzacji Spółki Akcyjnej Zarządu Portu Szczecin-Świnoujście, Szczecin, 11 stycznia 1994 r. 
In October, 1994 Doker-Port Sp. z o.o. ${ }^{31}$ was founded. The company was set up as a result of the fusion of The Szczecin and Świnoujście Seaports Authority, Drobnica-Port Szczecin Sp. z o. o and Elewator-Ewa Sp. $\mathrm{z}$ o.o. The foundation of a cargo-handling company as a result of transforming a department of port reserves of The Szczecin and Świnoujście Seaports Authority (SSSA) meant the implementation of SŚSA privatization plan.

The fact that the Ministry of Ownership Transformation did not approve the SŚSA privatization plan was caused by the government's work, which started in March, 1992, on preparing a draft of a new legal act on ports and sea havens. Due to changes of governments and to the fact that the port companies and the respective ministries had conflicting views on the issues in question it took three years for the document to be completed. ${ }^{32}$ On August 3, 1995, the Economic Committee of the Council of Ministers approved a draft of a new legislation act on ports and sea havens, ${ }^{33}$ which was later accepted by Józef Oleksy's government on October 17, 1995. ${ }^{34}$ On January 11, 1996, during a parliamentary debate the Minister of Transport and Sea Industries, Mr Bogusław Liberadzki while presenting the draft said that its main goal is to separate in Polish ports the sphere of management from the operational sphere. The main principles of the plan included:

- creation of two new economic entities-The Szczecin Port Authority SA (Zarząd Portu Szczecin SA) and The Świnoujście Port Authority SA (Zarząd Portu Świnoujście SA);

- foundation of a new company-The Council of Szczecin-Świnoujście Port Companies SA (Towarzystwo Portowe Szczecin-Świnoujście

31 Ibidem, cat. no. 1724, c. 45-46, Informacja o realizacji programu...

32 http://orka2.sejm.gov.pl/Debata2.nsf/118b9e577f3ceeac125746d0030d0fa/8 a274191..., 6.04.2010.

33 APS, ZPS-Ś, cat. no. 1730, c. 32-33, Informacja Ministerstwa Transportu i Gospodarki Morskiej o stanie prac legislacyjnych nad projektem ustawy o portach i przystaniach morskich oraz o zmianie niektórych ustaw [Information from the Ministry of Transport and Maritime Economy on legislative process on Port and Harbour Bill and changing some other acts].

34 http://orka2.sejm.gov.pl/Debata2.nsf/118b9e577f3ceeac125746d0030d0fa/ 06df2e19..., 6.04.2010 
SA) whose goals would include coordinating the business and development of the two ports;

- economic activity of The Szczecin and Świnoujście Seaports Authorities including operation and management of the suprastructure which belonged to the State Treasury;

- conducting port services by respective port companies.

The governmental bill of the legal act on ports and havens was criticized by MPs from various political options ${ }^{35}$ who claimed that creating two independent management centers for the port in Szczecin and Świnoujście could lead to their rivalry, could limit their potential of accumulating capital necessary for infrastructure investment, weaken the position of the ports with regard to the competition. ${ }^{36}$ The foundation of The Council of Szczecin-Świnoujście Port Companies SA (Towarzystwo Portowe Szczecin-Świnoujście SA) was met with fears and doubts. According to MP A. Szarawarski ${ }^{37}$ the Ministry of Transport and Maritime Economy could use the company to manage the two ports. Additionally, all the decisions of these companies would be handed over to him. Consequently, the decision taking process (concerning the ports' development) would be lengthy and complicated. According to the deputies A. Szarawarski and B. Kaczmarek the Ministry of Transport and Maritime Economy should be the managing centre for all Polish ports. ${ }^{38}$

The bill of ports and sea havens was criticized by the board of the Szczecin and Świnoujście Seaports Authority. While the bill was being worked on, the board repeatedly informed the Ministry of Transport and Maritime Economy as well as the Ministry of Ownership Transformation that it supported maintaining a unity of the management of the two ports

35 These MPs included: Leszek Chwat (Democratic Union), Jan Wołek (Polish Peasant Party), Longin Pastusiak (Democratic Left Alliance), Krzysztof Luks (Democratic Union), Bogusław Kaczmarek (Labour Union), Andrzej Szarawarski (Democratic Left Alliance). Ibidem.

36 Ibidem.

37 http://orka2.sejm.gov.pl/Debata2.nsf/118b9e577f3ceeac125746d0030d0fa/ eb2c39aa..., 6.04.2010.

38 http://orka2.sejm.gov.pl/Debata2.nsf/118b9e577f3ceeac125746d0030d0fa/752e a631.., 6.04.2010. 
of Szczecin and Świnoujście. ${ }^{39}$ This solution would also make it possible for the two ports to more effectively compete with other ports (in areas such as servicing large vessels with grain and metallurgical products). Additionally, proposals were addressed to the above mentioned ministries with plans of founding a company that would manage the port of Szczecin and Swinoujście as a result of the transformation of the already existing company. ${ }^{40}$ The negative opinion expressed by the board of SSSA was also due to the complex structure in the management system of the ports of Szczecin and Świnoujście. ${ }^{41}$

Owing to the stand most deputies and the board of SŚSA took about the governmental bill on ports and sea havens, changes were made in the draft plan during the legislative process. The act of law adopted by the $\mathrm{Sejm}^{42}$ (the lower house of parliament in Poland) guaranteed a unified system of managing the two ports. On the basis on this legislative act, on 29 June, 1998, the The Szczecin and Świnoujście Seaports Authority SA was founded, in which $51 \%$ of the shares belonged to the State Treasury and $24.5 \%$ was given to Szczecin Gmina and Świnoujście Gmina respectively. ${ }^{43} \mathrm{~A}$. Montwiłł became the chairman of the newly created company, who at the same time was the chairman of the board of SŚSA SA. ${ }^{44}$ The

39 APS, ZPS-Ś, cat. no. 1714, c. 30, Uchwała Nr 2 Zarządu Spółki Akcyjnej Zarząd Portu Szczecin-Świnoujście podjęta w dniu 11 czerwca 1992 r.

40 Ibidem, cat. no. 1495, c. 73, Pismo do Pana Czyżewskiego Podsekretarza Stanu w Ministerstwie Skarbu Państwa, 3 kwietnia 1997 r. [A letter to Mr Czyżewski - Undersecretary of State In the Ministry of Treasury, April 3, 1997].

41 The structure included the Ministry of Transport and Maritime Economy, Towarzystwo Portowe Szczecin-Świnoujście SA (The Szczecin-Świnoujście Port Association SA), two port authorities (Zarząd Portu Szczecin SA, Zarząd Portu Świnoujście SA), and port companies. Ibidem.

42 Ustawa z dnia 20 grudnia 1996 r. o portach i przystaniach morskich. DzU 1997, nr 9, poz. 44 [Port and Harbour Act of December 20, 1996. Journal of Laws of the Republic of Poland No. 9 of 1997, item 44].

43 „Gazeta Wyborcza”, October 20, 1998.

44 APS, ZPS-Ś, cat. no. 1626, c. 57, Pismo do Pana Adama Kowalewskiego Dyrektora Departamentu Administracji Morskiej, Żeglugi i Rybołówstwa Ministerstwa Transportu i Gospodarki Morskiej, 14 września 1998 r. [A letter to Adam Kowalewski - the Head of the Maritime, Shipping and Fishery Administration Department of the Minisitry of Transport and Maritime Economy, September 14, 1998]. 
act of law concerning ports and sea havens assumed that these two companies would combine. However, the process was halted because the legal act turned out to be faulty. If the new company had taken over the old one it would have led to "a loss of the right to acquire a block of 15 free employee stock, guaranteed by the act of commercialization and privatization of state companies." 45 Given this situation, the trade unions of SSSSA refused to give their go-ahead for the fusion of the two companies. ${ }^{46}$ The existence of the two companies (ZMPS-Ś SA and ZPS-Ś SA) both active in the same line of business, led to dualism which had a negative effect on the development of the ports in Szczecin and Świnoujście. ${ }^{47}$ In June, 1999, an amendment of the act on ports and havens was made. ${ }^{48}$ The change in legislation made the incorporation of the two companies possible and it also guaranteed acquisition of the shares by eligible employees. On December 15, 1999, the two companies (ZMPS-Ś SA and ZPS-Ś SA) combined. In the middle of May, 2000, the shares were given to the eligible employees. At the same time in 2007, SSSSA fully complied with the statutes of the legal act on ports and sea havens and sold the shares which had belonged to the State Treasury of the operational companies. ${ }^{49}$ By this act the sphere of management was separated from the sphere of port operations.

The process of changing the ownership status of the port company was a consequence of political and economic changes which marked Polish history since the late 1980s. The organizational and structural changes of the company aimed at separating the function of managing the land and facilities in the ports in Szczecin and Świnoujście from the sphere of their day-to-day operation. As a result, a complete privatization of port companies dealing with servicing vessels and land transport had taken place.

45 “Rzeczpospolita", December 10,1999.

46 “Gazeta Wyborcza”, December 19,1999.

47 Ibidem, December 18,1999.

48 Ustawa z dnia 18 czerwca 1999 r. o zmianie ustawy o portach i przystaniach morskich. DzU 1999, nr 62. poz. 685 [Act amending the Port and Harbour Act of June 18, 1999. Journal of Laws of the Republic of Poland No. 62 of 1999, item 685].

49 http://www.magazynportowy.pl/polski/p-r-m-a-519/magazyn_portowy_nr 12_2007.h..., 7.04.2010. 
These changes led to an improvement of financial results of The Szczecin and Świnoujście Seaports Authority.

In the first years of the company's business activity, the structural and organizational changes were the decisions made of the company's authorities. It is also difficult to clearly provide the circumstances owing to which the Ministry of Ownership Transformation did not take a stance on the privatization plan prepared by The Szczecin and Świnoujście Seaports Authority. The sale of shares of the port companies was the implementation of the new act of legislation on ports and sea havens. 